... Ayrilmis, Akbulut: Screw Withdrawal Resistance and Surface Soundness of Three-Layer ...

\title{
Screw Withdrawal Resistance and Surface Soundness of Three-Layer Fiberboard Having Coarse Fibers in Core Layer
}

\section{Otpornost prema izvlačenju vijaka i međuslojna čvrstoća troslojne ploče vlaknatice s grubim vlaknima u središnjem sloju}

\author{
Original scientific paper $\bullet$ Izvorni znanstveni rad \\ Received-prispjelo: 14. 2. 2018. \\ Accepted-prihvaćeno: 27. 11. 2018. \\ UDK: $630 * 812.791 ; 630 * 863.312$ \\ doi:10.5552/drind.2018.1804
}

\begin{abstract}
Screw withdrawal resistance (SWR) and surface soundness of three-layer MDF were investigated and the results were compared to the single-layer MDF. For this aim, effects of various formulation variables such as coarse fiber length (24.4 to $4.3 \mathrm{~mm}$ ), resin content (10.5 to $6.5 \mathrm{wt} \%)$ in the core layer, average panel density (730 to $\left.650 \mathrm{~kg} / \mathrm{m}^{3}\right)$, and surface/core layer ratio (70/30 to 30/70) were determined. The face and edge SWR and surface soundness of three-layer MDF panels were determined according to EN 320 and EN 311 standards, respectively. The results showed that the face SWR and edge SWR of MDF panels improved as the fiber length increased from 4.3 to $11.5 \mathrm{~mm}$ in the core layer. Similar results were determined for the surface soundness. The surface soundness of MDF panels improved with increasing fiber length in the core layer up to $17.8 \mathrm{~mm}$. SWR and surface soundness improved with increasing resin content in the core layer, shelling ratio, and panel density.
\end{abstract}

Keywords: coarse fiber, resin, surface soundness, screw withdrawal resistance, three-layer fibreboard

SAŽETAK • U radu je prikazano istraživanje otpornosti prema izvlačenju vijaka i međuslojne čvrstoće troslojne $M D F$ ploče, a rezultati su uspoređeni sa svojstvima jednoslojne MDF ploče. Za tu su svrhu istraživani učinci različitih parametara na pripremu ploče, primjerice duljina grubih vlakana $(24,4-4,3 \mathrm{~mm})$ i sadržaj smole (6,5 $-10,5 \%)$ u središnjem sloju, prosječna gustoća ploče (650 to $\left.730 \mathrm{~kg} / \mathrm{m}^{3}\right)$ i omjer površinskoga i središnjeg sloja (70/30 - 30/70). Otpornost prema izvlačenju vijaka na licu i rubu ploče te međuslojna čvrstoća ispitivane su prema normama EN 320 i EN 311. Rezultati su pokazali da se otpornost prema izvlačenju vijaka na licu i rubu ploče povećala s povećanjem duljine vlakana u središnjem sloju s 4,3 na 11,5 mm. Slični su rezultati utvrđeni i za međuslojnu čvrstoću. Naime, međuslojna se čvrstoća MDF ploča također povećala s povećanjem duljine vlakana u središnjem sloju sve do 17,8 mm. Otpornost prema izvlačenju vijaka i međuslojna čvrstoća ploča povećale su se i s povećanjem udjela smole u središnjem sloju, omjera površinskoga i središnjeg sloja te gustoće ploče.

Ključne riječi: gruba vlakna, smola, međuslojna čvrstoća, otpornost prema izvlačenju vijaka, troslojna ploča vlaknatica

\footnotetext{
${ }^{1}$ Authors are Professors at Department of Wood Mechanics and Technology, Forestry Faculty, Istanbul University-Cerrahpasa, Bahcekoy, 34473, Sariyer, Istanbul, Turkey.

Autori su profesori Odsjeka za mehaniku drva i tehnologiju, Šumarski fakultet, Sveučilište u Istanbulu-Cerrahpasa, Istanbul, Turska.
} 


\section{INTRODUCTION}

\section{UVOD}

Medium density fiberboard (MDF) is a woodbased panel made from fine wood fibers with resin under heat and pressure. It is one of the most commonly used wood-based panels in the furniture industry due to its favorable properties such as good mechanical properties and surface quality, and good machinability. In the traditional MDF production, surface and core layers are made from fine wood fibers. However, the core layer of the particleboard is mostly made from coarse wood particles, while the surface layers are made from fine wood particles. This technology can be applied to MDF production process. Due to a shortage in the supply of wood material and transportation costs, MDF manufacturers are forced to decrease panel density having acceptable technological properties.

Costs reduction in MDF production can be attained in two ways. The first possibility is the modernization and optimization of defibration process. The second one is the change of the structure of MDF boards (Danuta and Marcin, 2014). This study focused on the second way, i.e. the three-layer MDF production process. Three-layer wood-based panels having coarse fibers or particles in the core layer have some significant advantages as compared to single-layer panels such as lower resin consumption in the core layer and lower panel cost (Ayrilmis et al., 2017).

In this study, three-layer MDF panels were produced under laboratory conditions. Increasing fiber size in the core of MDF and optimizing the fiber size in the core could improve edge and surface SWR and surface soundness of MDF. The effects of various formulation variables such as coarse fiber length, resin content in the core layer, average panel density, and surface/core layer ratio on SWR and surface soundness of three-layer MDF panels were investigated.

\section{MATERIALS AND METHODS}

\section{MATERIJALI I METODE}

\subsection{Wood fibers}

\subsection{Drvna vlakna}

The pine (Pinus sylvestris) and beech (Fagus orientalis Lipsky) wood chips steamed in a digester at 170

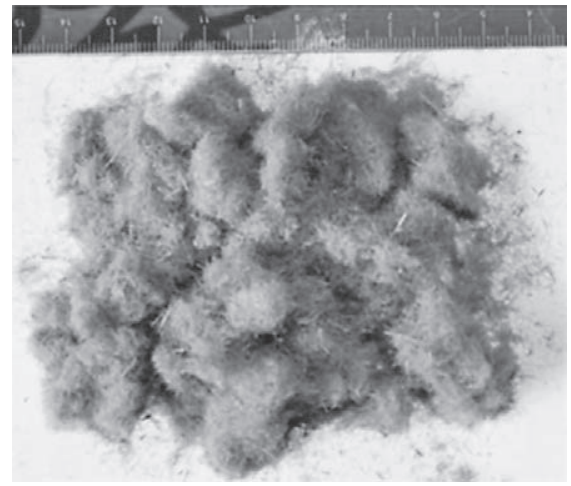

a)
${ }^{\circ} \mathrm{C}$ and 8 bar for 4 min were converted to wood fibers using a thermo-mechanical refining process at Kastamonu Integrated Wood Company, Gebze, Turkey. The wet fibers in the plastic bags were transported to the Faculty of Forestry, Istanbul University-Cerrahpasa, where the boards were produced. The fibers were dried in a dryer until 2-3\% based on the oven-dry weight of wood fiber. Fine pine wood fibers were used in the face layers, while the coarse beech wood fibers were used in the core layer of MDF panels (Figure 1). The defibrator gap distance was adjusted to $0.4 \mathrm{~mm}$ for the surface layer fibers, while it was gradually increased to $1.2 \mathrm{~mm}$ for the core layer fibers. The length and thickness of 100 randomly selected fibers from core layer (five different sizes) and surface layers were measured using Brinell microscope 10X (Alfred J Amsler and Co).

\subsection{Resin}

\subsection{Smola}

A commercial liquid E1 grade urea-formaldehyde (UF) resin with $50 \mathrm{wt} \%$ solid content was supplied by Kastamonu Integrated Wood Company, Gebze, Turkey. The density, viscosity, and gel time of the UF resin were $1.208 \mathrm{~g} / \mathrm{cm}^{3}, 26 \mathrm{cps}$, and $55 \mathrm{~s}$, respectively. Ammonium chloride $\left(\mathrm{NH}_{4} \mathrm{Cl}\right)$ solution with $20 \mathrm{wt} \%$ solid content was used as hardener for the UF resin.

\subsection{Production of three-layer MDF panels}

\subsection{Proizvodnja troslojne MDF ploče}

Three-layer MDF panels were produced under laboratory conditions (Figure 2). Different production parameters, effect of fiber size and resin content in the core layer, average panel density, and shelling ratio, were used in the production of three-layer MDF panels. (Table 1). The optimum fiber size in the core layer was determined based on the laboratory test results (panel types from A to E, Table 1). The size of surface fibers (pine fibers) was kept constant in all the panel types. As a hardener, $1 \mathrm{wt} \%$ ammonium chloride based on the solid content of the resin was added into the UF resin.

The surface and core layer fibers were separately glued with UF resin. First, the surface layer fibers were placed in a drum blender and then the UF resin based on the oven dry weight of the wood fiber was

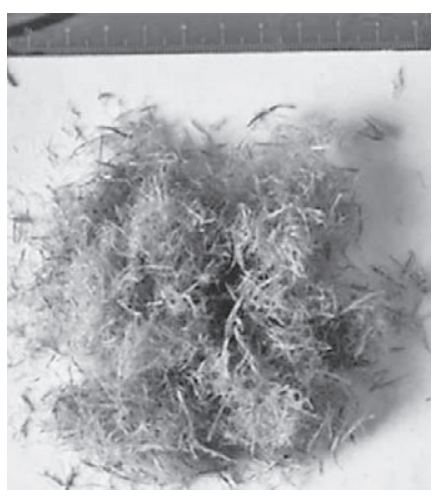

b)

Figure 1 a) Fine wood fibers (pine) used in face layers of MDF; b) Coarse wood fibers (beech) used in core layer of MDF Slika 1. a) Fina drvna vlakna (borovine) upotrijebljena u površinskom sloju MDF ploče; b) gruba drvna vlakna (bukovine) ugrađena u središnji sloj MDF ploče 


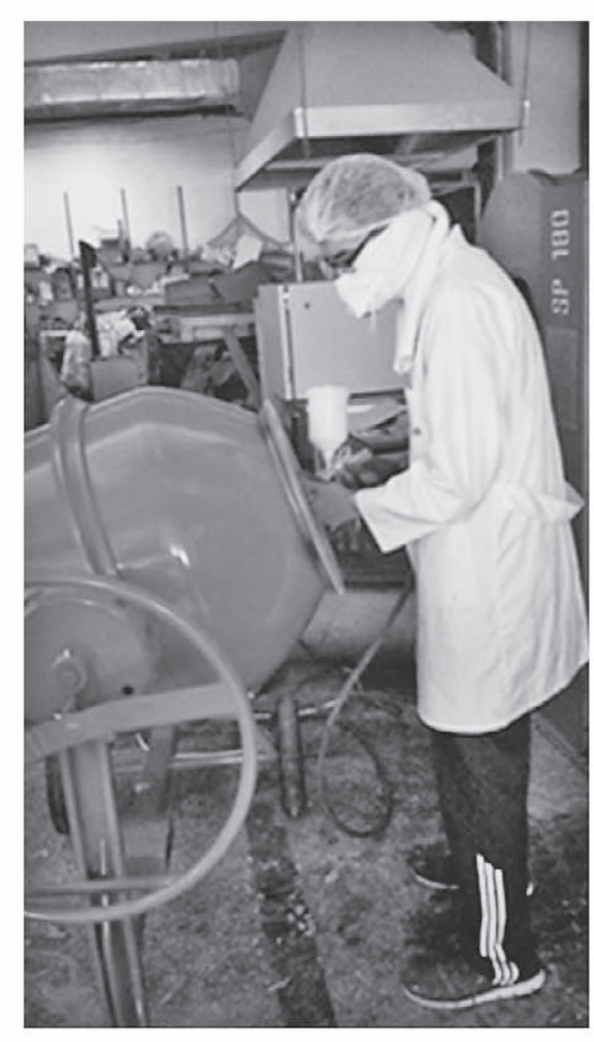

A

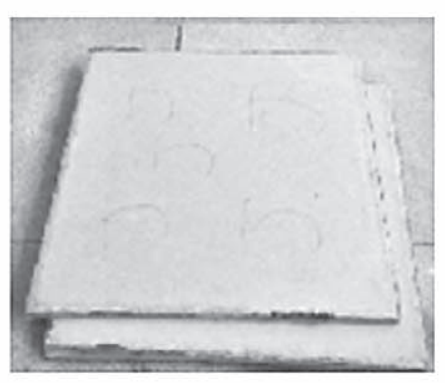

D
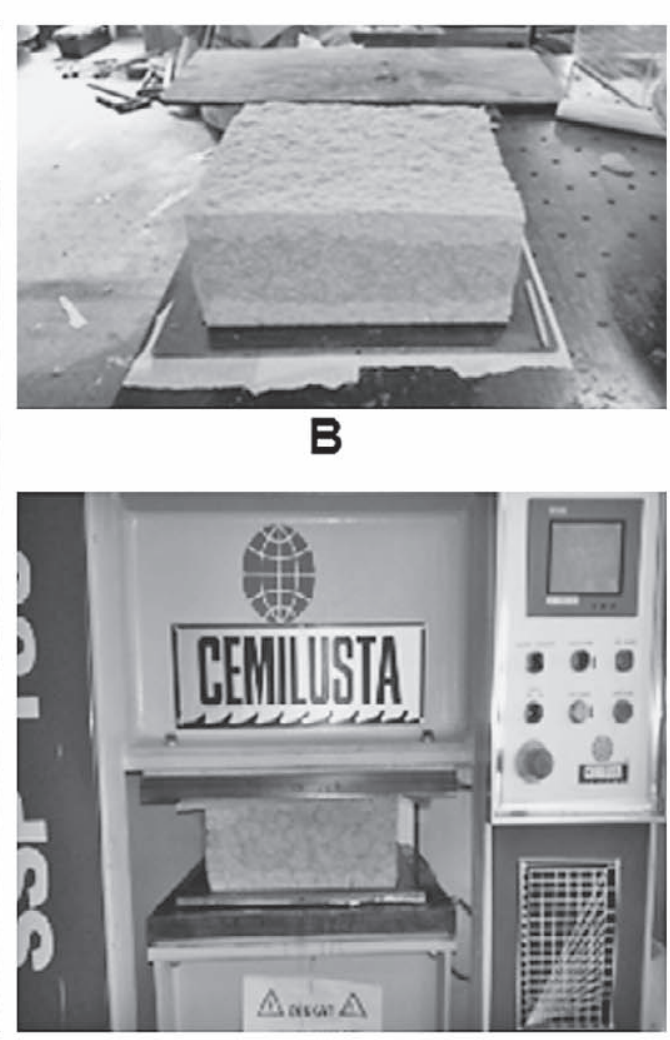

C

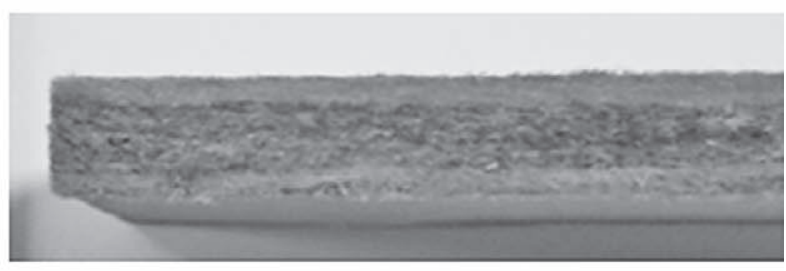

E

Figure 2 Process of production of three-layer MDF panels produced in laboratory, A - Resin application to wood fibers, B - Three layer-mat preparation, C - Hot pressing, D - Three-layer MDF panels, E - Cross section of three layer MDF panel Slika 2. Postupak proizvodnje troslojne MDF ploče u laboratoriju: A - nanošenje smole na drvna vlakna, B - priprema slojeva, C - vruće prešanje, D - troslojna MDF ploča, E - presjek troslojne MDF ploče

applied with an air-atomized metered spray system for $5 \mathrm{~min}$ to obtain a homogenized mixture. This procedure was also applied to the core layer fibers. The surface and core fibers of three-layer boards were separately weighed and distributed evenly by hand into a $400 \mathrm{~mm}$ x $400 \mathrm{~mm}$ forming box. The mat was sandwiched between aluminum cauls with siliconized paper to prevent adherence between panel and caul. The mats were manually cold pressed and then transferred to the hot press operated in plate position control mode. Hot pressing temperature, maximum hot press pressure, and total press time for MDF panels having a density of $700 \mathrm{~kg} / \mathrm{m}^{3}$ were $190{ }^{\circ} \mathrm{C}, 3.5 \mathrm{~N} /$ $\mathrm{mm}^{2}$, and $480 \mathrm{sec}$, respectively. The maximum hot press pressure was gradually decreased from 3.5 to $3.1 \mathrm{~N} / \mathrm{mm}^{2}$ to obtain $10 \mathrm{~mm}$ thick MDF panels having different densities (700 to $650 \mathrm{~kg} / \mathrm{m}^{3}$ ), while it was increased to $3.6 \mathrm{~N} / \mathrm{mm}^{2}$ to produce MDF panels having a density of $730 \mathrm{~kg} / \mathrm{m}^{3}$.

Three panels were prepared from each MDF type given in Table 1. The test specimens were conditioned in a climatic chamber at $20{ }^{\circ} \mathrm{C}$ and $65 \%$ relative humidity until the specimens reached constant weight. The experimental design is presented in Table 1. 
Table 1 Experimental design

Tablica 1. Plan istraživanja

\begin{tabular}{|c|c|c|c|c|c|c|c|}
\hline \multirow[b]{2}{*}{$\begin{array}{c}\text { Production } \\
\text { parameters } \\
\text { Parametri proizvodnje }\end{array}$} & \multirow{2}{*}{\multicolumn{2}{|c|}{$\begin{array}{c}\text { Face layers } \\
\text { ratio, wt\% } \\
\text { Udio } \\
\text { površinskih } \\
\text { slojeva, wt } \%\end{array}$}} & \multirow[b]{2}{*}{$\begin{array}{l}\text { Core layer } \\
\text { ratio, wt\% } \\
\text { Udio } \\
\text { središnjeg } \\
\text { sloja, wt } \%\end{array}$} & \multicolumn{2}{|c|}{ Core layer / Središnji sloj } & \multirow[b]{2}{*}{$\begin{array}{c}\text { Target } \\
\text { density of } \\
\mathbf{M D F}, \\
\mathbf{k g} / \mathbf{m}^{3} \\
\text { Ciljana } \\
\text { gustoća } \\
\text { MDF ploče, } \\
\mathrm{kg} / \mathrm{m}^{3}\end{array}$} & \multirow[b]{2}{*}{$\begin{array}{c}\text { Resin } \\
\text { content in } \\
\text { core layer, } \\
\text { wt\% } \\
\text { Sadržaj } \\
\text { smole u } \\
\text { središnjem } \\
\text { sloju, wt } \%\end{array}$} \\
\hline & & & & $\begin{array}{c}\text { Coarse fiber } \\
\text { length in core } \\
\text { layer, mm } \\
\text { Duljina grubih } \\
\text { vlakana } u \\
\text { središnjem sloju, } \\
\text { mm } \\
\end{array}$ & $\begin{array}{c}\text { Coarse fiber } \\
\text { thickness in } \\
\text { core layer, mm } \\
\text { Debljina grubih } \\
\text { vlakana } u \\
\text { središnjem sloju, } \\
\mathrm{mm} \\
\end{array}$ & & \\
\hline \multirow{5}{*}{$\begin{array}{l}\text { Effect of fiber size in core } \\
\text { layer of MDF } \\
\text { utjecaj veličine vlakana u } \\
\text { središnjem sloju MDF } \\
\text { ploče }\end{array}$} & A & 50 & 50 & $4.3(0.5)$ & $0.51(0.03)$ & 700 & 10.5 \\
\hline & B & 50 & 50 & $7.9(0.8)$ & $0.65(0.04)$ & 700 & 10.5 \\
\hline & $\mathrm{C}$ & 50 & 50 & $11.5(0.8)$ & $0.73(0.04)$ & 700 & 10.5 \\
\hline & $\mathrm{D}$ & 50 & 50 & $17.8(0.6)$ & $0.79(0.03)$ & 700 & 10.5 \\
\hline & $\mathrm{E}$ & 50 & 50 & $24.4(1.1)$ & $0.94(0.05)$ & 700 & 10.5 \\
\hline \multirow{5}{*}{$\begin{array}{l}\text { Effect of resin content in } \\
\text { core layer of MDF } \\
\text { utjecaj sadržaja smole u } \\
\text { središnjem sloju MDF } \\
\text { ploče }\end{array}$} & $\mathrm{F}$ & 50 & 50 & $11.5(0.8)$ & $0.73(0.04)$ & 700 & 10.5 \\
\hline & G & 50 & 50 & $11.5(0.8)$ & $0.73(0.04)$ & 700 & 9.5 \\
\hline & $\mathrm{H}$ & 50 & 50 & $11.5(0.8)$ & $0.73(0.04)$ & 700 & 8.5 \\
\hline & I & 50 & 50 & $11.5(0.8)$ & $0.73(0.04)$ & 700 & 7.5 \\
\hline & $\mathrm{J}$ & 50 & 50 & $11.5(0.8)$ & $0.73(0.04)$ & 700 & 6.5 \\
\hline \multirow{5}{*}{$\begin{array}{l}\text { Effect of surface/core } \\
\text { layer ratio } \\
\text { utjecaj omjera } \\
\text { površinskoga } i \\
\text { središnjeg sloja }\end{array}$} & $\mathrm{K}$ & 70 & 30 & $11.5(0.8)$ & $0.73(0.04)$ & 700 & 10.5 \\
\hline & $\mathrm{L}$ & 60 & 40 & $11.5(0.8)$ & $0.73(0.04)$ & 700 & 10.5 \\
\hline & $\mathrm{M}$ & 50 & 50 & $11.5(0.8)$ & $0.73(0.04)$ & 700 & 10.5 \\
\hline & $\mathrm{N}$ & 40 & 60 & $11.5(0.8)$ & $0.73(0.04)$ & 700 & 10.5 \\
\hline & $\mathrm{O}$ & 30 & 70 & $11.5(0.8)$ & $0.73(0.04)$ & 700 & 10.5 \\
\hline \multirow{4}{*}{$\begin{array}{l}\text { Effect of average panel } \\
\text { density } \\
\text { utjecaj prosječne } \\
\text { gustoće ploče }\end{array}$} & $P$ & 50 & 50 & $11.5(0.8)$ & $0.73(0.04)$ & 725 & 10.5 \\
\hline & $\mathrm{R}$ & 50 & 50 & $11.5(0.8)$ & $0.73(0.04)$ & 700 & 10.5 \\
\hline & $\mathrm{S}$ & 50 & 50 & $11.5(0.8)$ & $0.73(0.04)$ & 675 & 10.5 \\
\hline & $\mathrm{T}$ & 50 & 50 & $11.5(0.8)$ & $0.73(0.04)$ & 650 & 10.5 \\
\hline
\end{tabular}

Note: The average length and thickness of the fibers used in the face layers of MDF were $4.3 \mathrm{~mm}$ and $0.51 \mathrm{~mm}$, respectively.

Napomena: Prosječna duljina i debljina vlakana upotrijebljenih u slojevima lica MDF ploče iznosile su 4,3 mm i 0,51 mm.

\subsection{Determination of screw withdrawal resistance and surface soundness of MDF}

2.4. Određivanje otpornosti prema izvlačenju vijaka i međuslojne čvrstoće MDF ploče

The surface and edge SWR of MDF specimens with dimensions of $50 \mathrm{~mm}$ x $50 \mathrm{~mm}$ x $10 \mathrm{~mm}$ were determined according to EN 320 standard. Predrilling was applied to the face and edges of MDF specimens before inserting screws into MDF. 10 specimens for the surface SWR and 10 specimens for the edge SWR were used in the experiments. The densities of $15 \mathrm{MDF}$ specimens with dimensions of $50 \mathrm{~mm}$ x $50 \mathrm{~mm}$ x $10 \mathrm{~mm}$ were measured according to EN 323. The surface soundness test of 10 specimens with dimensions of $50 \mathrm{~mm} \times 50$ $\mathrm{mm} \times 10 \mathrm{~mm}$ was carried out according to EN 311 .

\subsection{Statistical analysis}

\subsection{Statistička analiza}

The results were statistically analyzed by analysis of variance $(p<0.05)$ to evaluate the effects of material formulation on SWR and surface soundness of MDF specimens. Significant differences among the mean values of MDF types were determined using Duncan's multiple range test.

\section{RESULTS AND DISCUSSION 3. REZULTATI I RASPRAVA}

The surface and edge SWR results of MDF specimens depending on the material formulation are given in
Figure 3. As the wood fiber size in the core layer increased from 4.3 to $11.5 \mathrm{~mm}$, the surface SWR increased from 652 to $719 \mathrm{~N}$. As for the edge SWR, it increased from 490 to $575 \mathrm{~N}$ as the fiber length increased from 4.3 to $17.8 \mathrm{~mm}$ in the core layer. However, further increment in the fiber length decreased the surface and edge SWR of MDF specimens. A similar result was observed for the particleboards (García-Ortuño et al., 2011). They reported that SWR improved with increasing particles size up to a certain point. The surface and edge SWR of single-layer MDF (panel type A), having the same fiber size in the core and surface layers, were found to be 652 $\mathrm{N}$ and $490 \mathrm{~N}$, respectively. The results showed that the face and edge SWR of three-layer MDF were better than single-layer MDF (Figure 3). The surface and edge SWR of three-layer MDF types C, D, and E showed significant difference $(\mathrm{p}<0.05)$ with MDF type A (singlelayer), while MDF type B did not show such a significant difference. The higher SWR of three-layer MDF panels having coarse fibers in the core layer as compared with single-layer MDF could be due to the ability of the coarse fibers to conform around the thread of the screw, allowing continuous load transfer along the thread.

The increases in the resin content and panel density improve bond performance between the fibers in the core layer of particleboards (Post, 1961; Warmbier et al., 2013; Benthien and Ohlmeyer, 2017) and MDF (Wold, 2010; Danuta and Marcin, 2014), thus improving SWR of MDF. There was no significant difference in SWR as the resin content decreased from 10.5 to $9.5 \mathrm{wt} \%$. How- 
ever, further decrement in the core layer significantly decreased SWR. As the panel density decreased from 730 to $650 \mathrm{~kg} / \mathrm{m}^{3}$, the surface SWR of MDF panels decreased from 755 to $659 \mathrm{~N}$. SWR improved with increasing surface layer ratio from 30 to $70 \mathrm{wt} \%$. The surface of the fibers is well covered by the resin as the amount of the resin in the core layer is increased. In addition, the resin fills the micro voids in the core layer, which improves SWR. The weakness of the core layer of wood-based panels, such as MDF and particleboard, is mainly responsible for lower edge SWR due to its higher porosity than that of face layers. The edge and surface SWR of MDF panels were positively affected by the shelling ratio. Similar results were observed in previous studies (Akbulut, 1998; Istek et al., 2017). The surface SWR increased from 675 to $791 \mathrm{~N}$ as the surface layer ratio increased from 30 to $70 \mathrm{wt} \%$. A similar result was observed for the edge SWR, which increased from 515 to $584 \mathrm{~N}$. There was no significant difference in SWR values between $30 \mathrm{wt} \%$ and $40 \mathrm{wt} \%$ surface layer ratios.

The results of surface soundness of MDF panels showed a similar trend to the results of SWR (Figure 4). The surface soundness of MDF specimens improved with increasing fiber size in the core layer. As the fiber length increased from 4.3 to $17.8 \mathrm{~mm}$, the surface sound- ness increased from 1.08 to $1.33 \mathrm{~N} / \mathrm{mm}^{2}$. However, further increment in the fiber size decreased the surface soundness. MDF type A showed no significant difference with MDF type B, but other panel types from $\mathrm{C}$ to E showed significant difference with the panel type A. The surface soundness of MDF specimens increased with increasing coarse fiber length (up to $17.8 \mathrm{~mm}$ ) (Figure 4). The specific surface area of longer particles is lower than that of shorter particles of the same species at the same MDF density. More resin was required to sufficiently bond the fibers as the fiber size was decreased. Thus, the resin content per unit particle surface area is higher for long particles than for short ones at a given resin content, which improves the bond performance between the fibers (Benthien et al., 2014).

The increase in the resin content in the core layer improved the surface soundness of MDF specimens. This was expected because the resin improved the bond strength between the surface layer (fine fibers) and core layer (coarse fibers). There was no significant difference in the surface soundness values of MDF specimens as the resin content decreased from 10.5 to $8.5 \mathrm{wt} \%$ in the core layer, this being resin saving that could be obtained. However, further decrement in the resin content significantly decreased the surface soundness. The contact area

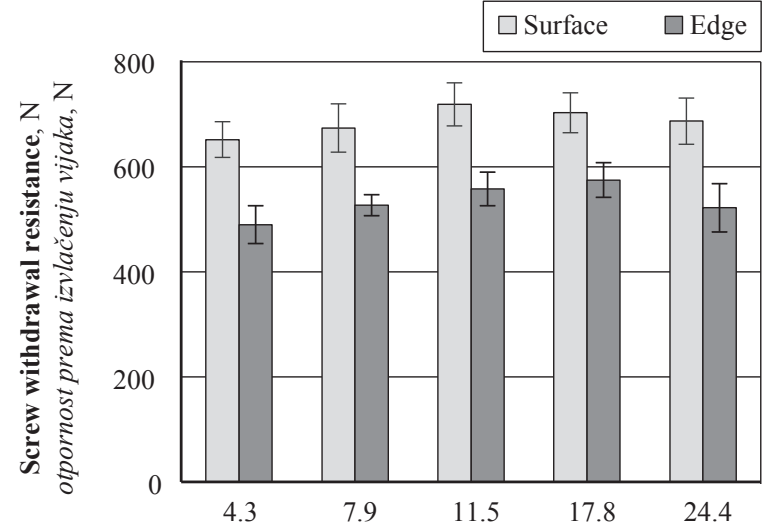

Coarse fiber length in the core layer of MDF, mm duljina grubih vlakana u središnjem sloju MDF ploče, $\mathrm{mm}$

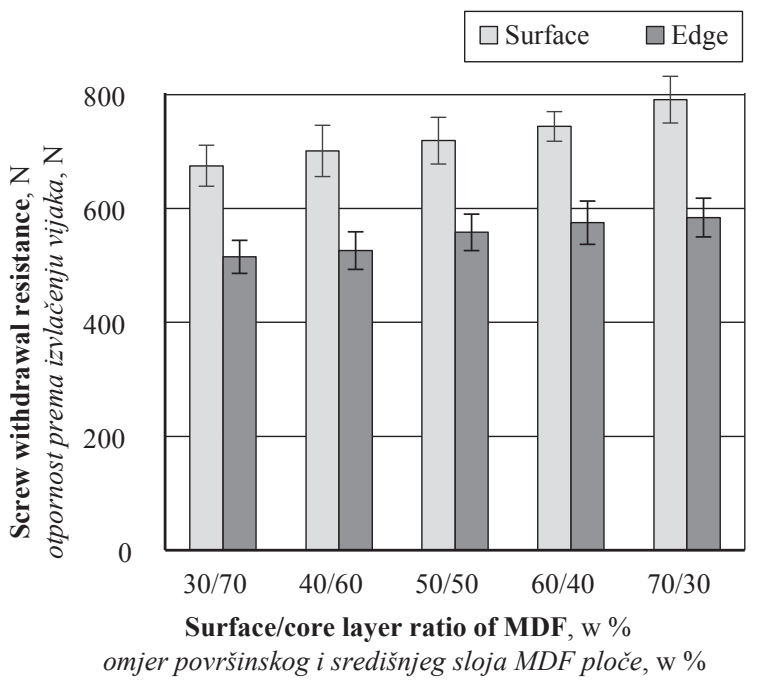

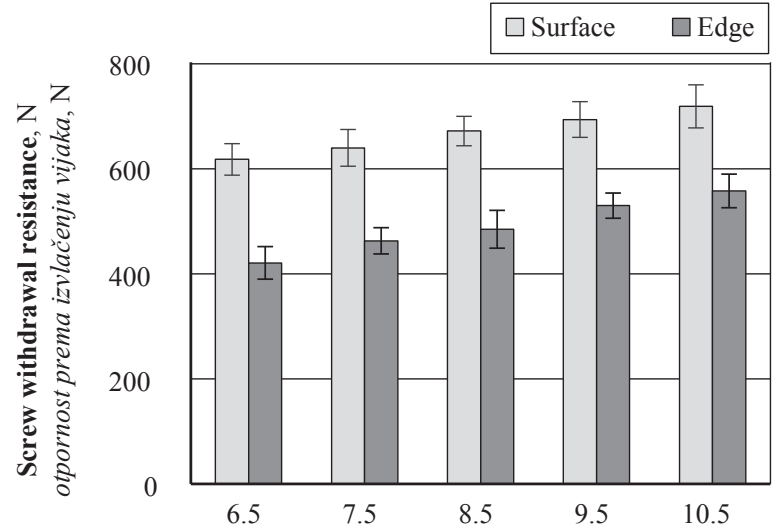

Resin content in the core layer of MDF, w \% udio smole u središnjem sloju MDF ploče, w \%

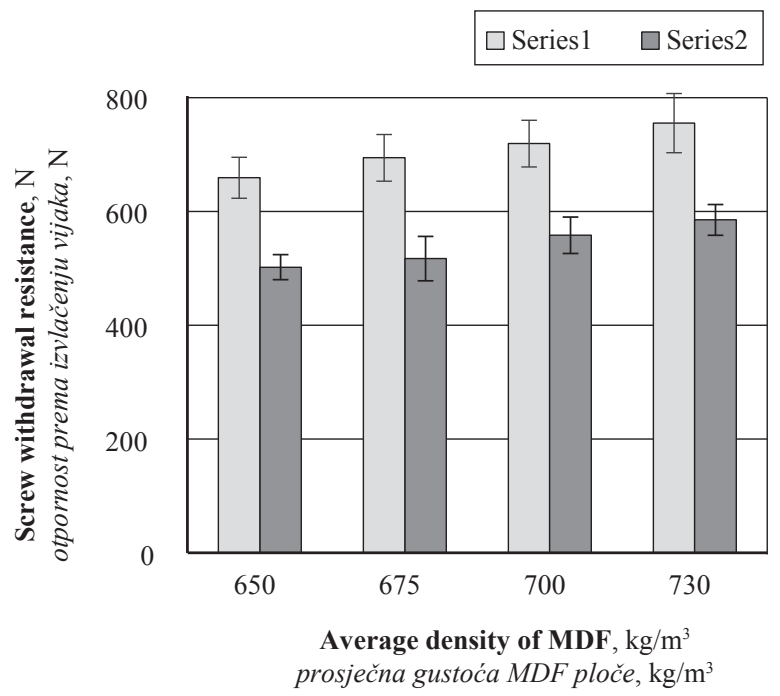

Figure 3 Screw withdrawal resistance of three-layer MDF depending on manufacturing conditions

Slika 3. Otpornost troslojne MDF ploče prema izvlačenju vijaka u ovisnosti o uvjetima proizvodnje 


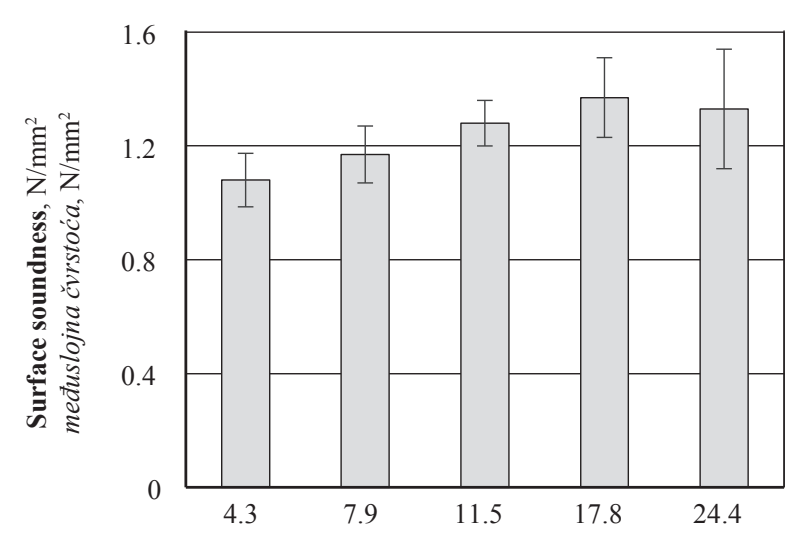

Coarse fiber length in the core layer of MDF, mm duljina grubih vlakana u središnjem sloju MDF ploče, $\mathrm{mm}$

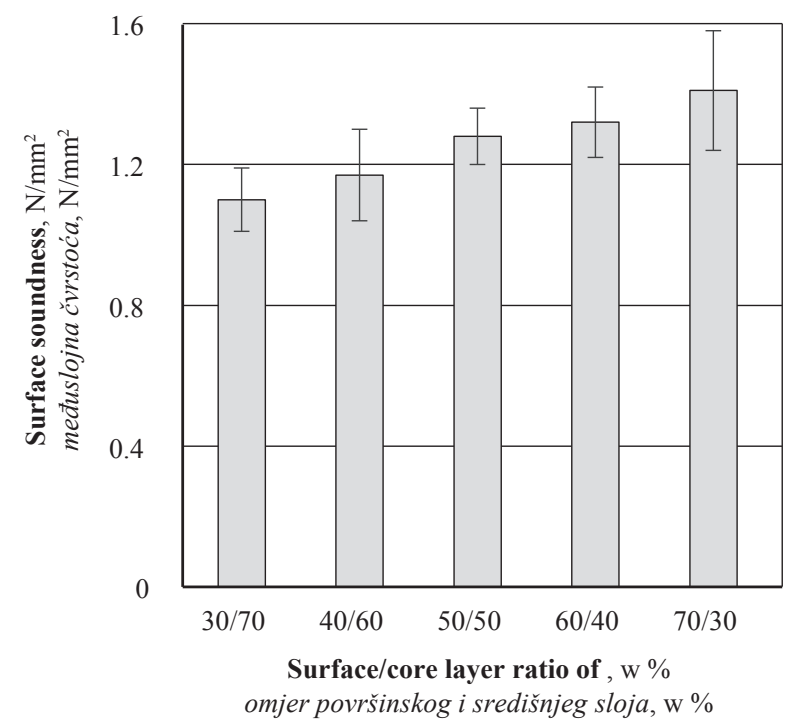

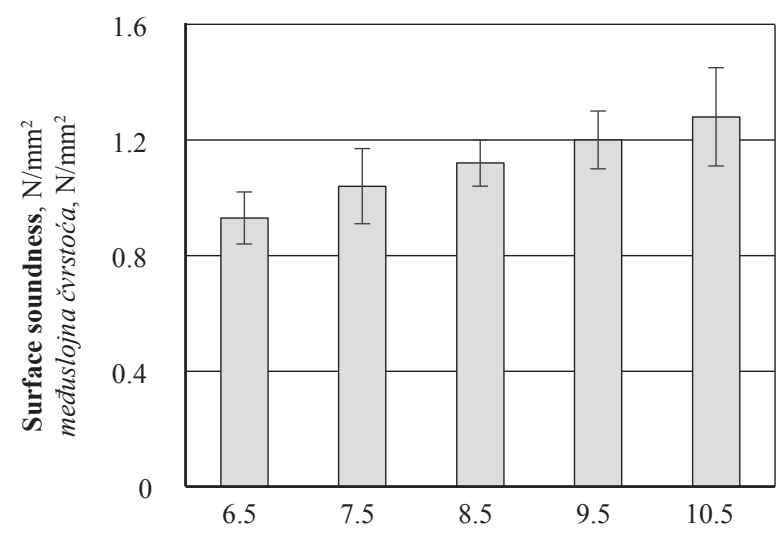

Resin content in the core layer of MDF, w \% udio smole u središnjem sloju MDF ploče, w \%

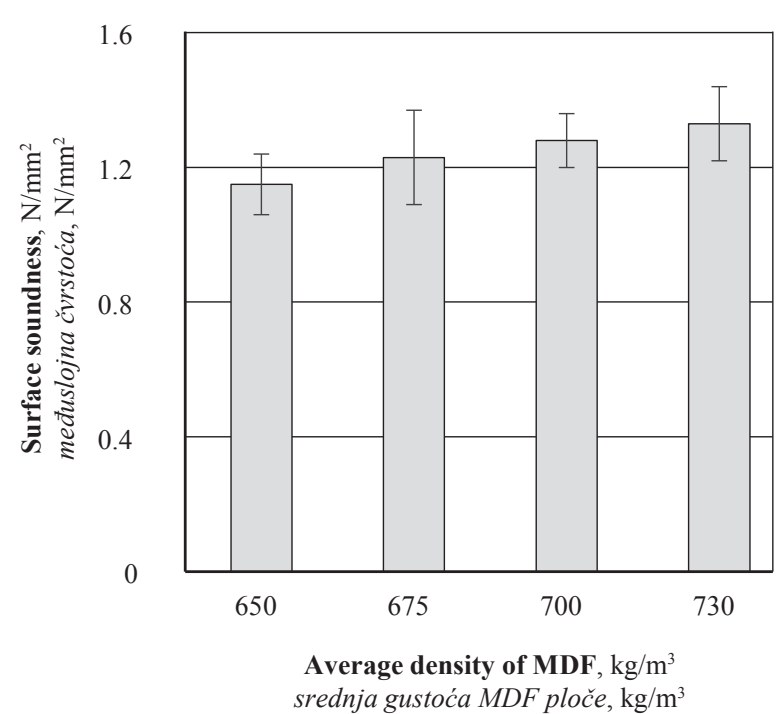

Figure 4 Surface soundness of three-layer MDF depending on manufacturing conditions Slika 4. Međuslojna čvrstoća troslojne MDF ploče u ovisnosti o uvjetima proizvodnje

between the wood fibers increases with increasing density of MDF. This improves the bond performance of the connection area of the resin as compared to MDF having lower density, which increases the surface soundness and SWR. As the panel density is increased, stronger connections are produced due to the higher contact area between the fibers and their higher overlap (Suchsland and Woodson, 1986). Similar results were observed in previous studies (Hong et al., 2017).

The increase in the surface layer ratio from 30 to $70 \mathrm{wt} \%$ improved the surface soundness of MDF panels $\left(1.10\right.$ to $\left.1.41 \mathrm{~N} / \mathrm{mm}^{2}\right)$. Panel type $\mathrm{N}$ showed no significant differences with panel types $\mathrm{O}$ and $\mathrm{P}$, but it showed significant differences with panel types $\mathrm{R}$ and $\mathrm{S}$. As the amount of the surface layer made from fine fibers was increased, more compact structure was obtained. This may improve the delamination strength between surface and core layers.

\section{CONCLUSIONS \\ 4. ZAKLJUČAK}

SWR and surface soundness of three-layer MDF was found better than single-layer MDF as the surface layers of the panels were made from softwood fine fibers and the core layer was made from hardwood coarse fibers. The surface SWR increased as the fiber length increased from 4.3 to $11.5 \mathrm{~mm}$ and the edge SWR increased as the fiber length increased from 4.3 to 17.8 $\mathrm{mm}$. The surface soundness of the wood fibers improved as the fiber length in the core layer was increased by 17.8 $\mathrm{mm}$. There was no significant difference in SWR of $\mathrm{MDF}$ as the resin content decreased from 10.5 to 8.5 $\mathrm{wt} \%$ in the core layer. SWR and surface soundness improved with increased shelling ratio and average panel density. The resin consumption in the three-layer MDF production can be reduced by $15 \%$ compared with the single-layer MDF. This was because the coarse fibers in the core layer decreased the resin consumption due to decreased surface area as compared to the fine fibers in the single layer MDF. Energy consumption and resin savings are important factors influencing MDF price. The decreases in the resin content and panel density can be significant advantages of three-layer MDF as compared to the single-layer MDF, resulting in a decrease in the production cost of MDF.

\section{Acknowledgements - Zahvala}

This work was supported by the Scientific and Technological Research Council of Turkey (TUBITAK) under Grant 114O263. 
... Ayrilmis, Akbulut: Screw Withdrawal Resistance and Surface Soundness of Three-Layer ...

\section{REFERENCES}

\section{LITERATURA}

1. Akbulut, T., 1998: The effect of various manufacturing variables on technological properties of particleboard. Journal of Istanbul University Forest Faculty, 48: 91-116.

2. Ayrilmis, N.; Akbulut, T.; Yurttas, E., 2017: Effects of core layer fiber size and face-to-core layer ratio on the properties of three-layer fiberboard. BioResources, 12: 79647974. https://doi.org/10.15376/biores.12.4.7964-7974.

3. Benthien, J. T.; Ohlmeyer, M., 2017: Influence of faceto-core layer ratio and core layer resin content on the properties of density-decreased particleboards. European Journal of Wood and Wood Products, 75: 55-62. https://doi.org/10.1007/s00107-016-1059-5.

4. Danuta, N.; Marcin, K., 2014: Possibility of the production of three-layer MDF. Annals of Warsaw University of Life Sciences - SGGW Forestry and Wood Technology, 88: 162-169.

5. García-Ortuño, T.; Andréu-Rodríguez, J.; FerrándezGarcía, M. T.; Ferrández-Villena, M.; Ferrández-García, C. E., 2011: Evaluation of the physical and mechanical properties of particleboard made from giant reed (Arundo donax L.). BioResources, 6: 477-486.

6. Hong, M. K.; Lubis, M. A. R.; Park, B. D., 2017: Effect of panel density and resin content on properties of medium density fiberboard. Journal of Korean Wood Science and Technology, 45: 444-455. https://doi.org/10.5658/wood.2017.45.4.444.

7. Istek, A.; Kursun, C.; Aydemir, D.; Koksal, S. E.; Kelleci, O., 2017: The effect of particle ratios of surface layers on particleboard properties. Journal of Bartin University Foresty Faculty, 19: 182-186.

8. Post, P. W., 1961: Relationship of flake size and resin content to mechanical and dimensional properties of flake board. Forest Products Journal, 11 (9): 34-37.
9. Suchsland, O.; Woodson, G. E., 1987: Fiberboard Manufacturing Practices in the United States. U.S. Department of Agriculture, Forest Service, Madison WI, USA.

10. Warmbier, K.; Wilczyński, A.; Danecki, L., 2013: Effects of density and resin content on mechanical properties of particleboards with the core layer made from willow Salix viminalis. Annals of Warsaw University of Life Sciences - SGGW Forestry and Wood Technology, 84: 284287.

11. Wold, D., 2010: The EVO 56 Defibrator system - the obvious choice at Medite; Metso Results Pulp \& Paper 3/2010: 26-27 (www.metso.com/pulpandpaper).

12. *** 2012: EN 311. Wood-based panels. Surface soundness. Test method. European Committee for Standardization, Brussels, Belgium.

13. *** 2011: EN 320. Particleboards and fibreboards. Determination of resistance to axial withdrawal of screws. European Committee for Standardization, Brussels, Belgium.

14. *** 1993: EN 323. Determination of density. European Committee for Standardization, Brussels, Belgium.

\section{Corresponding address:}

Prof. dr. NADIR AYRILMIS, Ph.D.

Department of Wood Mechanics and Technology Forestry Faculty, Istanbul University-Cerrahpasa. Bahcekoy, Sariyer 34473, Istanbul, TURKEY

e-mail: nadiray@istanbul.edu.tr 